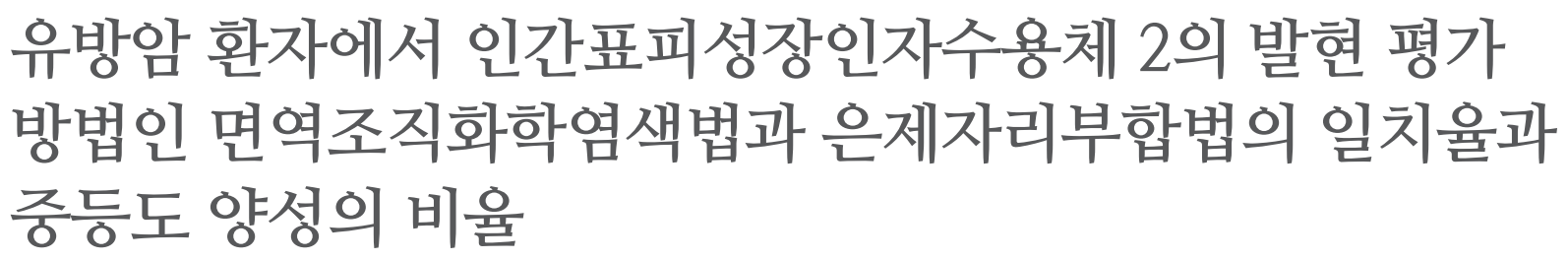

권순하, 이득영, 이종은, 이지현 ${ }^{1}$, 한선욱, 김성용, 백무준, 이현주 ${ }^{2}$, 오미혜 ${ }^{2}$

순천향대학교 천안병원 외과, ${ }^{1}$ 순천향대학교 서울병원 외과, ${ }^{2}$ 순천향대학교 천안병원 병리과

\title{
Concordance and Proportion of Equivocal Results of Silver-Enhanced In Situ Hybridization and Immunohistochemical Technique for the Determination of HER2 Amplification in Breast Cancer Patients
}

\author{
Soon Ha Kwon, Deuk Young Lee, Jong Eun Lee, Jihyoun Lee ${ }^{1}$, Sun Wook Han, Sung Yong Kim, Moo Jun Baek, \\ Hyun Ju Lee ${ }^{2}$, Mee-Hye $\mathrm{Oh}^{2}$ \\ Department of Surgery, Soonchunhyang University Cheonan Hospital, Soonchunhyang University College of Medicine, Cheonan; ${ }^{1}$ Department of \\ Surgery, Soonchunhyang University Seoul Hospital, Soonchunhyang University College of Medicine, Seoul; ${ }^{2}$ Department of Pathology, \\ Soonchunhyang University Cheonan Hospital, Soonchunhyang University College of Medicine, Cheonan, Korea
}

\begin{abstract}
Purpose: Information on the status of human epidermal growth factor receptor 2 (HER2) is important for treatment planning in breast cancer; therefore, equivocal results of HER2 overexpression obtained using immunohistochemical staining (IHC) require additional evaluation regarding HER2 amplification, which can be obtained by other techniques such as fluorescence in situ hybridization (FISH) assay. The silver-enhanced in situ hybridization (SISH) technique is known to be comparable with FISH and can be performed under a bright field microscope. In this study, the authors evaluated the concordance between the results obtained by IHC and SISH used for determining HER2 status. Methods: Paraffin-embedded tissues from 511 breast cancer patients were prepared and the medical records of the patients were reviewed. HER2 amplification status was evaluated by SISH assay by determining the HER2/chromosome 17 ratio or HER2 copy number status. The slides were blindly reviewed without IHC information. Results: Among the collected tissues, invasive ductal carcinoma was detected in 440 patients (86.1\%) and 27 (5.3\%) showed ductal carcinoma in situ. The concordance rate between the results obtained by IHC and SISH was $90.6 \%$ ( $\mathrm{K}=0.723$ ). Two cases of negative IHC results had equivocal SISH results. Conclusion: SISH was found to be a useful method for evaluating HER2 status in case of an equivocal result of IHC.
\end{abstract}

Key Words: Breast neoplasms, Human epidermal growth factor receptor 2, Immunohistochemical staining, Silver-enhanced in situ hybridization

\section{서 론}

유방암에서 발견되는 유전자의 이상은 여러 가지가 보고되고 있 지만 그중에서도 가장 흔한 것은 종양억제 유전자인 $p 53$ 유전자의

\section{Correspondence: Sung Yong Kim}

Department of Surgery, Soonchunhyang University Cheonan Hospital, Soonchunhyang University College of Medicine, 31 Suncheonhyang 6-gil, Dongnam-gu, Cheonan 330-721, Korea

Tel: +82-41-570-2140, Fax: +82-41-571-0129, E-mail: sykim@schmc.ac.kr

Received: September 17, 2014 Accepted: November 24, 2014
변이와 인간표피성장인자수용체 2 (human epidermal growth factor receptor 2, HER2) 종양유전자의 활성화에 의한 증폭이다[1,2]. HER2 종양유전자는 17번 염색체(chromosome 17)에 존재하는 유전자로 유방암, 폐암, 난소암 및 위암 등에서 발현이 관찰되며, 특히 유방암 에서 HER2 종양유전자의 증폭이나 단백질의 과발현은 전체 유방 암 환자의 $10 \%-34 \%$ 에서 관찰되는 것으로 보고되고 있다[3]. HER2 종양유전자를 검색하는 방법으로는 HER2 종양유전자 DNA의 증 폭을 검색하거나 $\mathrm{mRNA}$ 혹은 단백질의 과발현을 검색하는 방법들 이 있는데, 임상적으로는 면역조직화학염색법(immunohistochemis- 
try, $\mathrm{IHC}$ )이 가장 많이 이용되고 있다. 그러나 IHC는 신속하고 경제 적이며 보편성을 가진 반면 반정량적 정도로 판독되므로 판독의사 에 따라서 주관적인 판독을 초래할 수 있다는 단점이 있다[4].

HER2 종양유전자 단백질의 과발현은 대부분 DNA 증폭에 의해 일어나므로 고정된 세포 또는 조직 절편 위에서 직접 HER2 종양유 전자 DNA의 증폭을 검색하는 방법도 이용되는데, 이 중 형광제자 리부합법(fluorescence in situ hybridization, FISH)이 가장 광범위하 게 시행되고 있다. $\mathrm{FISH}$ 는 DNA 자체가 매우 안정적이므로 파라핀 포매 조직(paraffin-embedded tissue)에서도 시행할 수 있고, IHC보 다조직의 상태에 민감하지 않으며 병리의사간의 판독 일치율이 높 다는 장점이 있으나, 검사 과정이 복잡하고 형광 현미경이 필요하며, DNA 탐색자의 가격이 비싼 단점이 있고, 형광 신호의 빠른 소실로 결과의 영구 보존이 불가능하다는 단점이 있다[5]. 반면 은제자리부 합법(silver-enhanced in situ hybridization, $\mathrm{SISH}$ )은 FISH와 유사한 정확도를 보이며, 일반 광학 현미경을 이용하여 판독할 수 있고, 결 과의 영구적인 보존이 가능하다[6,7].

본 연구는 유방암 환자의 조직을 이용하여 IHC 결과를 참고하지 않은 상태에서 $\mathrm{SISH}$ 를 이용하여 HER2 종양유전자 DNA의 증폭을 조사하였고, 기존의 HER2 종양유전자 단백의 발현을 조사하는 IHC 결과와비교하였다.

\section{방 법}

2001년 1월부터 2013년 1월까지 순천향대학교 천안병원에서 유방 암으로 수술을 시행 받은 환자들 중 분석이 가능하고, 유전자 동의 를 받았던 511예의 포르말린에 고정된 파라핀 포매 조직(formalinfixed and paraffin-embedded tissues)을 선택하여 이들의 의무 기록 을 고찰하였다. 또한 본 연구는 본 원의 임상시험계획심사위원회(Institutional Review Board) 승인을 받았다(승인번호: 2014-10-020-001).

한 환자당 6 개의 조직을 채취해 tissue microarray (TMA) 블록을 만든 후, $4 \mu \mathrm{m}$ 두께로 잘라 일차 항체로 rabbit anti-HER2 antibody (PATHWAY ${ }^{\circledR}$; Ventana Medical Systems, Tucson, USA)를 사용했고, 일차항체의 탐지는 ultraView Universal DAB Detection Kit (Ventana Medical Systems)를 이용해 IHC을 시행하였다. IHC의 반정량적평 가(semiquantitative assessment)는 한 명의 병리학자가 임상병리학 적 결과와 유전자 증폭(gene amplification) 상태를 모르는 상태에 서 판정하였다. HER2에 대한 IHC 판정은 American Society of Clinical Oncology and the College of American Pathologists (ASCO/CAP) guidelines를 따랐다[8].

SISH는 2개의 연속된 TMA 절편에 HER2 Dual ISH DNA Probe
Cocktail (INFORM $^{\circledR}$; Ventana Medical Systems)과 Chromosome 17 DIG Probe (Ventana Medical Systems)를 사용해 시행했다. HER2와 chromosome 17에 대한 SISH 신호들은 한 개의 표본당 얻어지는 20 개 이상의 서로 다른 핵에 대해서, IHC에 의한 HER2 결과를 모르 는 상태에서 Olympus ${ }^{\circledR}$ System Microscope BX53 (× 1,000 magnification; Olympus Corp., Tokyo, Japan)을 사용해 분석하였다. 만약 분 석 중에 종양 내 핵의 다형태(polymorphism)가 발견되면, 그 때는 100 개 이상의 서로 다른 핵을 분석하였다. HER2와 chromosome 17 의 단일복사를 하나의 점(dot)으로 세었다. 이러한 각각의 점의 크기 는 종양세포핵에서 증폭된 절편의 상대적인 개수를 결정하는 데 참 고로 사용되었으며 여러 신호로 이루어진 하나의 작은 군집은 6 으 로, 큰 군집은 12 로 분류되었다. HER2 종양유전자 복제 수가 6 이상 이거나 혹은 HER2/chromosome 17의 비율이 2.2 이상이면 SISH 양 성으로(이하 positive), HER2 종양유전자 복제 수가 4 와 6 사이 혹은 HER2/chromosome 17의 비율이 1.8 과 2.2 사이인 경우는 SISH 중 등도 양성(이하 equivocal)으로, 그리고 HER2 종양유전자 복제 수 가 4 이하 혹은 HER2/chromosome 17 의 비율이 1.8 이하인 경우는 $\mathrm{SISH}$ 음성(이하 negative)으로 정의하였다. 림프구, 섬유모세포, 그리 고 정상 관상피세포는 내부 통제요인으로 사용되었다.

통계학적 분석은 SPSS version 19.0 (IBM Corp., Armonk, USA)을 사용했다. IHC와 SISH 사이의 일치율은 concordance cases/total cases로 구하였고, Cohen's $\kappa$ test를 이용하여 분석하였으며 신뢰구 간은 $95 \%$ 이다. $\kappa$ 값은 $0.00-1.00$ 의 범위를 가지고 있는데 각 $\kappa$ 값은 $<0.00$ 은 불량(poor), $0.00-0.20$ 은 약간 일치(slight), $0.21-0.40$ 는 어 느 정도 일치(fair), $0.41-0.60$ 은 중등도 일치(moderate), $0.61-0.80$ 은 상당한 일치(substantial), $0.81-1.00$ 은 거의 일치(almost perfect)로 받 아들여진다[9].

\section{결 과}

분석 대상이 된 511명의 연령분포는 24 세에서 83 세였으며, 중앙 연령(median age)은 50세였다. 이 중 256명은 유방보존술(breastconserving surgery)을, 255명은 유방절제술(mastectomy)을 시행 받 았으며, 남성 유방암이 6예(1.2\%) 포함되어 있었다. World Health Organization 분류[10]에 의한 조직학적 분류는 침윤성 유관암(invasive ductal carcinoma NOS)이 440예(86.1\%)로 대부분을 차지하였 고, 그 외에 관상피내암종(ductal carcinoma in situ, DCIS) 27예(5.3\%), 침윤성 소엽암(invasive lobular carcinoma) 20예(3.9\%), 기타 암 종이 24예(4.7\%)가 있었다. 조직학적 등급(histologic grading)은 등급(이 하 grade) 1이 62예(12.3\%), grade 2가 260예(50.9\%), 그리고 grade 3가 
188 예(36.8\%)였고, 종양의 크기는 $0.3 \mathrm{~cm}$ 에서 $12 \mathrm{~cm}$ (중앙값, 2.46 $\mathrm{cm}$ )였다. 초기 종양 크기의 자료가 있었던 478예 중 pT1이 231예 (45.2\%), pT2가 221예(43.2\%), 그리고 PT3가 25예(4.9\%)로 분류되었다. 환자의 특성은 Table 1에 요약되어 있다.

HER2 종양유전자에 대한 IHC 결과는 음성이 270예(52.8\%), 부

Table 1. Baseline characteristics of patients

\begin{tabular}{|c|c|}
\hline Characteristic & №. (\%) \\
\hline Total & $511(100.0)$ \\
\hline \multicolumn{2}{|l|}{ Age (yr) } \\
\hline$<50$ & $245(47.9)$ \\
\hline$\geq 50$ & $266(52.1)$ \\
\hline \multicolumn{2}{|l|}{ Sex } \\
\hline Female & $505(98.8)$ \\
\hline Male & $6(1.2)$ \\
\hline \multicolumn{2}{|l|}{ Type of surgery } \\
\hline Breast-conserving surgery & $256(50.1)$ \\
\hline Mastectomy & $255(49.9)$ \\
\hline \multicolumn{2}{|l|}{ Histologic type } \\
\hline DCIS & $27(5.3)$ \\
\hline Ductal & $440(86.1)$ \\
\hline Lobular & $20(3.9)$ \\
\hline Others & $24(4.7)$ \\
\hline \multicolumn{2}{|l|}{ Histologic grade } \\
\hline 1 & $63(12.3)$ \\
\hline 2 & $260(50.9)$ \\
\hline 3 & $188(36.8)$ \\
\hline \multicolumn{2}{|l|}{ T stage } \\
\hline Tis & $27(5.3)$ \\
\hline $\mathrm{T} 1$ & $231(45.2)$ \\
\hline $\mathrm{T} 2$ & $221(43.2)$ \\
\hline $\mathrm{T} 3$ & $25(4.9)$ \\
\hline T4 & $7(1.4)$ \\
\hline \multicolumn{2}{|l|}{ Stage } \\
\hline 0 & $27(5.3)$ \\
\hline I & $170(33.3)$ \\
\hline$\|$ & $216(42.3)$ \\
\hline III & $85(16.7)$ \\
\hline IV & $13(2.5)$ \\
\hline
\end{tabular}

$\mathrm{DCIS}=$ ductal carcinoma in situ .
분적 혹은 약양성인 $1+$ 가 119 예(23.3\%), 중등도 양성인 2+가 46예 (9.0\%), 양성인 3+가 76예(14.9\%)로 나타났다. 음성과 부분적 혹은 약 양성인 1+의 경우를 HER2 negative군으로, 중등도 양성인 2+를 HER2 equivocal군으로, 그리고 양성인 3+를 HER2 positive군으로 분류하여 보았을 때, 511예 중 negative군, equivocal군, 그리고 positive군의 IHC 결과는 각각 389예(76.1\%), 46예(9.0\%) 그리고 76예 (14.9\%)로 나타났다. HER2 종양유전자에 대한 SISH 결과는 negative군, equivocal군, 그리고 positive군이 각각 411예(80.4\%), 2예 (0.4\%), 그리고 98예(19.2\%)를 보였다(Table 2).

IHC와 SISH 결과는 463개의 표본(IHC와 SISH 모두 negative군 과 IHC와 SISH 모두 positive군)에서 일치했으며, 일치율은 90.6\% (463/511)에 달했고, $\kappa$ 값(Cohen's $\kappa$ test) 0.723 으로 상당한 정도에서 일치율(substantial agreement)을 보였다(Table 2). IHC equivocal군 46 표본을 배제한 경우 두 방법 간의 일치율은 99.6\% (463/465)로 산 출되었다(Cohen's $\kappa$ test $=0.977$ ). 또한 $\mathrm{IHC}$ 가 positive군으로 판단된 경우는 SISH와 결과가 모두 positive군으로 일치했다(Figure 1).

$\mathrm{IHC}$ 검사에서 equivocal군으로 판단된 경우 SISH 검사에서도 equivocal군으로 나타나는 경우는 보이지 않았으며, IHC negative군 중 2예에서 SISH 검사에서 equivocal군으로 나타났다(Figure 2). IHC 검사에서 equivocal군은 총 46 예로 이 중 24 예(52.2\%)에서 SISH 검사 에서 negative군으로 분류되었고, 이를 제외한 22예(47.8\%)에서 positive군으로 나타났으며, 이 모든 경우에서 SISH 검사 결과 equivocal 군으로 보이지 않았다. 이들 46예의 American Joint Committee on Cancer TNM 암 병기를 살펴보면 0기 암이 4예(8.7\%), I기 암이 13예 (28.3\%), II기 암이 21예(45.6\%), III기 암은 7예(15.2\%), 그리고 IV기 암 은 1 예(2.2\%)로 나타났다. 환자 기록을 살펴보면 46명 중 6명(13.0\%) 에서 국소 전이나 원발 전이 소견을 보였다. 이들 6 명의 환자 중 4 명은 SISH 검사에서 positive군이었고, 2 명은 SISH 검사에서 negative군이 었으며, SISH 검사에서 positive군 환자 4 명 중 2 명에서만 trastuzumab 치료가이루어졌다.

$\mathrm{IHC}$ 검사에서 처음부터 positive군인 환자 75 명 중 11 명(14.7\%)에

Table 2. Comparison of immunohistochemistry and silver-enhanced in situ hybridization results

\begin{tabular}{|c|c|c|c|c|c|}
\hline & \multirow[b]{2}{*}{ No. (\%) } & \multicolumn{3}{|c|}{ SISH } & \multirow[b]{2}{*}{ K-value } \\
\hline & & $\begin{array}{c}\text { Negative } \\
\text { No. (\%) }\end{array}$ & $\begin{array}{c}\text { Equivocal } \\
\text { No. (\%) }\end{array}$ & $\begin{array}{l}\text { Positive } \\
\text { No. (\%) }\end{array}$ & \\
\hline $\mathrm{IHC}$ & & & & & 0.723 \\
\hline Negative & $389(76.1)$ & 387 (99.5) & $2(0.5)$ & 0 & \\
\hline Equivocal & $46(9.0)$ & $24(52.2)$ & 0 & $22(47.8)$ & \\
\hline Positive & $76(14.9)$ & 0 & 0 & $76(100.0)$ & \\
\hline Total & $511(100.0)$ & 411 (80.4) & $2(0.4)$ & $98(19.2)$ & \\
\hline
\end{tabular}

$\mathrm{SISH}=$ silver-enhanced in situ hybridization; $\mathrm{IHC}=$ immunohistochemistry. 


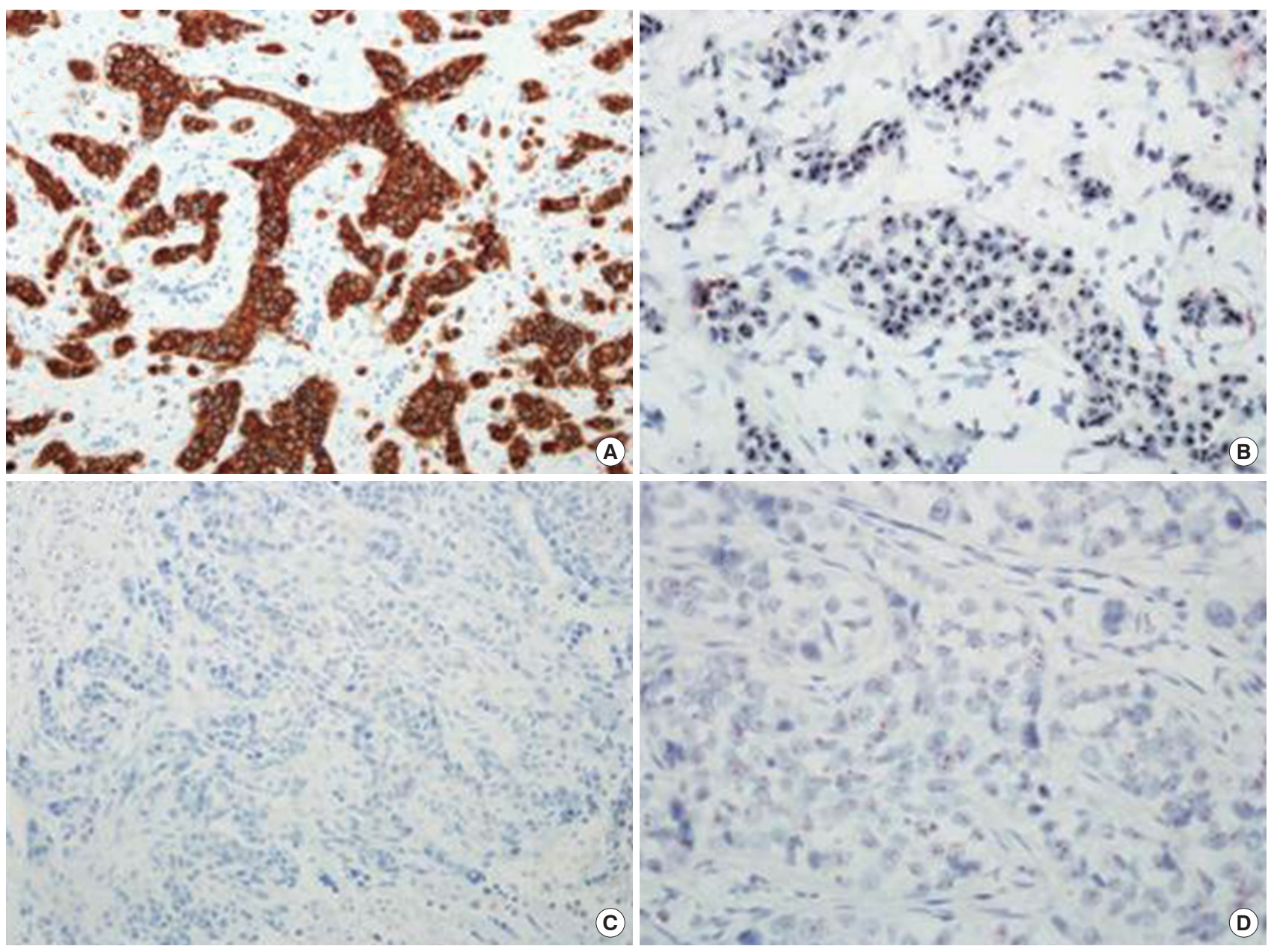

Figure 1. Concordance of immunohistochemistry $(\mathrm{IHC})$ and silver enhanced in situ hybridization (SISH) results for human epidermal growth factor receptor 2 (HER2). (A) Positive result in immunohistochemistry ( $\times 400)$. (B) HER2 amplification in SISH ( $\times 1,000)$. (C) Negative result in IHC ( $\times 400)$. (D) HER2 nonamplification in SISH $(\times 1,000)$. All of positive IHC revealed in concord with HER2 amplification in SISH, determined by absolute HER2 gene copy number and a HER2/chromosome 17 ratio (black dots, HER2 amplification; red dots, chromosome 17 signals). Most of Negative IHC showed nonamplification.

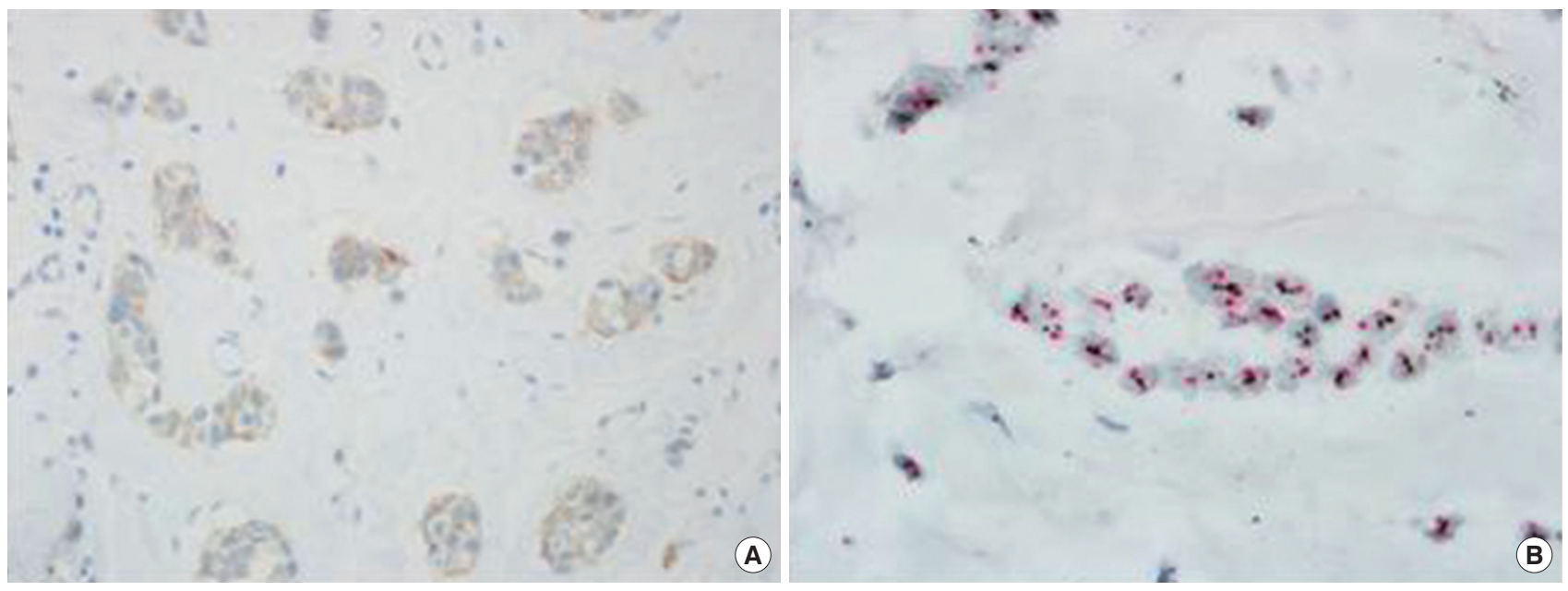

Figure 2. Disconcordance of immunohistochemistry (IHC) and silverenhanced in situ hybridization (SISH) results for human epidermal growth factor receptor 2 (HER2). (A) Negative result in IHC (×400). (B) Equivocal result in SISH $(\times 1,000)$. Tissue microarray which was negative (1+) in IHC was identified equivocal in SISH. 
서 국소 전이나 원발 전이 소견을 보였고, 11 명의 환자들 중 3 명만이 trastuzumab 치료를 받았다.

$\mathrm{IHC}$ 검사가 equivocal군인 환자들과 IHC 검사에서 처음부터 positive군인 환자들 중 많은 수의 환자가 오래 전 수술 받은 경우라 서 상당부분 추적관찰이 진행되지 못해 생존율 분석은 진행하지 못했다.

\section{고 찰}

HER2 종양유전자는 유방암의 발생에 관여할 뿐만 아니라, 치료 의 표적이 될 수 있는데, HER2 종양유전자 단백질의 세포 외 부분 에 대한 단일 항체인 trastuzumab이 HER2 종양유전자의 증폭이나 과발현 시에 표적치료제로 효과가 있고, 또한 HER2 종양유전자의 과발현을 보이는 경우 anthracycline 계열의 약물치료가 좋은 성적 을 보인 임상시험 결과와[11], tamoxifen보다 aromatase 억제제(inhibitor)의 효과가 상대적으로 높다는 보고도[12] 있으므로 HER2 종양유전자에 대한 정확한 평가는 유방암 환자에 있어 약물치료 선택에 중요한 의미를 지닌다[13].

HER2 종양유전자를 평가하는 방법은 여러 가지가 있으나 임상 에서는 세포막에서 HER2 종양유전자 단백의 과발현을 IHC 방법 을 통해 관찰하는 것이 가장 널리 이용되고 있다. HER2 종양유전자 의 증폭이 없으면 IHC에서 발현이 관찰되지 않거나 낮은 수준의 발 현을 보인다. 그러나 이 방법은 서로 다른 항체 및 조직의 전 처리 과 정에 따른 민감성의 차이로 다른 결과가 나타날 수 있으며[14], 연구 기관에 따라서도 IHC 결과가 상이하게 나타날 수 있는데, 이러한 결과는 $\mathrm{IHC}$ 가 반정량적으로 판독되어 판독의사에 따른 판독의 주 관성에 기인하는 것으로 밝혀져 있다[15,16]. 또한 IHC에서 equivo$\mathrm{cal}$ 군으로 판정되는 경우에는 치료 방침의 결정을 위하여 보다 정확 한 결과가 요구됨에 따라 FISH 방법이 개발되었고, 최근에는 SISH, chromogenic in situ hybridization (CISH) 등의 방법이 도입되어 이용 되고 있다.

Park과 Han [17]은 HER2 종양유전자의 과발현을 IHC와 FISH를 이용하여 비교하였는데, FISH 검색으로 HER2 종양유전자 증폭은 $24 \%-28 \%$ 의 빈도로 관찰되었고, IHC로 HER2 종양유전자 단백질 의 과발현은 $21 \%-27 \%$ 에서 관찰되었다. 두 가지 검사의 결과에서 전 체적인 종양유전자 증폭과 종양유전자 단백질의 과발현 사이에 빈 도는 비슷하게 나타났지만 IHC 결과가 equivocal군(2+)과 positive 군(3+)에서 HER2 종양유전자의 증폭과 단백질의 과발현 일치율은 각각 $45 \%-100 \%, 70 \%-100 \%$ 로 약간 상이한 것을 알 수 있다. Mass 등 [18]은 유방암 환자에서 trastuzumab 사용에 대한 임상 결과가
HER2 종양유전자의 과발현을 측정하는 IHC보다는 종양유전자 증폭을 관찰하는 FISH 방법을 따른다는 점으로 보아 HER2 종양 유전자의 평가에서 $\mathrm{FISH}$ 가 그 정확성에서 나은 결과를 예측할 수 있다. SISH는 FISH와 유사한 정확도를 보이며, 일반 광학 현미경을 이용하여 판독할 수 있고, 결과의 영구적인 보존이 가능하다는 장 점이 있다[19]. HER2 종양유전자 발현과 증폭에 관련하여 최근에 는 정량중합효소연쇄반응(quantitative polymerase chain reaction) 도 시도되고 있는데[20,21], 파라핀-포매 조직에서도 사용이 가능하 며, 적은 양의 조직으로도 분석이 용이한 장점이 있다.

2012년 Bae 등[22]은 6개 기관의 환자 959 명의 환자를 대상으로 하 여 IHC와 SISH를 이용하여 HER2 종양유전자 발현에 대한 다기관 연구를 진행하였다. 이 연구에 따르면 IHC와SISH 사이에 일치율은 거점 검사실(central laboratory)의 경우 $98.4 \%$ 로, SISH 또한 HER2 종 양유전자의 발현을 평가하는 데 의미 있게 사용할 수 있는 검사라 고할수있다.

본 연구에서도 511예의 표본 중에서 IHC와 SISH의 검사에서 결 과는 463예의 표본이 일치했고, HER2 종양유전자 과발현과 증폭 사이에 일치율은 $90.6 \%$ 이었다. 이는 Bae 등[22]의 연구와 비교해 보 았을 때 일치율의 차이가 있다고 보여지지만, Bae 등[22]의 연구에서 는 지역 검사실(local laboratory)의 IHC와 SISH의 일치율은 $90.3 \%$, 지역 검사실과 거점 검사실 간의 $\mathrm{IHC}$ 일치율은 $89.1 \%$ 였다는 점과 Papadopoulos 등[15]의 연구에서도 일반적으로 거점 검사실과 지역 검사실 간의 검사 결과 일치율이 $80.2 \%$ 이었다는 점, 그리고 본 연구 에서 IHC 방법으로 equivocal군 표본을 제외한 일치율은 $99.5 \%$ 였 다는 점을 고려할 때 다른 연구에 비해 큰 차이가 없다는 것을 알수 있다. 그러나, 본 연구는 한 명의 병리학자에 의해 HER2 발현이 평가 되어 결과 판정에 일관성이 있지만, 단일기관 연구이며 표본수가 적 고, 후향적 연구라는 점에 있어서는 제한성이 있다고 할 수 있겠다.

Meijer 등[23]이 발표한 IHC equivocal군인 553명의 환자를 포함 한 다기관 연구에서 CISH를 시행하였을 때, HER2 종양유전자의 과발현은 기관별로 상이하여 $0 \%$ 에서 $48.2 \%$ 까지 보고되었고, $\mathrm{CISH}$ equivocal군인 경우도 $0 \%$ 에서 $12.9 \%$ 까지 보고되었다. 우리가 시행 한 연구는 SISH로 시행되었으나, IHC equivocal군의 $48 \%$ 에서 SISH 방법으로 HER2 종양유전자 증폭이 발견되었고, 그중 SISH equivocal군은 $0 \%$ 로 나타나, 타 연구에 비해 SISH 양성률이 좀 더 높게 나타나는 경향을 보였다.

유럽에서 시행한 HERA Trial 참여환자 중 IHC 방법으로 equivocal군인 경우 FISH 방법을 시행하였는데, 대조군(trastuzumab 비 치료군)에서 HER2 copy number나 FISH ratio에 따른 무병생존율 을 분석한 결과 HER2 증폭 정도에 따라 예후에 차이를 보이지는 않 
았으며, trastuzumab 투약군에서도 HER2 증폭 정도와 치료의 효과 가 차이를 보이지는 않았다[24]. 따라서, IHC equivocal군의 경우 HER2 증폭 유무를 반드시 판정하여 HER2 유전자 증폭이 있다면 정도에 관계없이 trastuzumab의 치료가 의의가 있으며, FISH, SISH, 혹은 $\mathrm{CISH}$ 등을 이용한 HER2 과발현 검사가 IHC 검사에서 equivocal군으로 나온 환자들의 경우 임상적으로 매우 중요한 의의를 가 지는 것을 알수 있다.

본 연구 중 trastuzumab이 수술 후 보조요법으로 국내에서 보험 으로 인정되기 전인 2010년 10월 이전의 환자를 살펴보면, HER2 equivocal군인 환자 30 명 중 SISH negative군과 SISH positive군은 각 각 16 명과 14 명으로 나타났다. 이들 30 명의 환자 중 5 명(SISH negative군, 1명; SISH positive군, 4명)에서 국소 전이 및 원격 전이가 있었 고, 이 5 명의 환자들 중 1 명(SISH positive군)은 원격 전이로 인해 사 망하였다.

이미 여러 연구에서 HER2 종양유전자의 단백 과발현과 유전자 증폭은 불량한 예후와 관련되며, IHC, FISH, SISH 또는 CISH 검사 법을 이용한 결과 모두 다 유사한 결과 예측을 보여준 바 있다 [1,2,17,20,21]. 2007년 ASCO/CAP HER2 guideline이 발표된 이후 $\mathrm{HER} 2$ 의 FISH 검사법에서 equivocal군으로 분류되는 결과가 보고 되기 시작하면서, FISH positive군의 빈도가 줄어들고 equivocal군 이 2.6\%의 빈도로 나타났다[25]. 이러한 경우에 National Comprehensive Cancer Network guideline에서는 dual-probe ISH를 추가로 시행하도록 권고하고 있다.

일반적으로 IHC negative군에 대해서 FISH나 SISH 검사를 하지 않기 때문에 본 연구 결과와 같이 IHC negative군에서 SISH equivocal로 결과가 나타난 군에 관해서는 아직까지 연구된 바가 없으 며, 또한 SISH equivocal군 경우에 SISH positive군과의 예후에 차이 가 있는지에 대해서도 추가 연구가 필요할 것이다.

유방암에서 흔히 발견되는 HER2 종양유전자의 증폭은 유방암 의 발생에 관여할 뿐 아니라 특정 치료 약제에 대한 반응을 예측하 는 데에도 이용되고 있어 유방암 환자에서 HER2 검색은 필수적인 과정이 되었다. 본 연구의 결과와 같이 SISH는 HER2 발현을 IHC 보 다 정확히 평가할 수 있을 것으로 판단되며, 향후 유방암 환자의 맞 춤치료를 위한 환자군 선정에 도움이 될 것으로 기대된다.

\section{REFERENCES}

1. Beenken SW, Grizzle WE, Crowe DR, Conner MG, Weiss HL, Sellers MT, et al. Molecular biomarkers for breast cancer prognosis: $\mathrm{CO}^{-}$ expression of c-erbB-2 and p53. Ann Surg 2001;233:630-8.
2. Yamashita H, Nishio M, Toyama T, Sugiura H, Zhang Z, Kobayashi S, et al. Coexistence of HER2 over-expression and p53 protein accumulation is a strong prognostic molecular marker in breast cancer. Breast Cancer Res 2004;6:R24-30.

3. Ross JS, Fletcher JA. HER-2/neu (c-erb-B2) gene and protein in breast cancer. Am J Clin Pathol 1999;112(1 Suppl 1):S53-67.

4. Rhodes A, Jasani B, Anderson E, Dodson AR, Balaton AJ. Evaluation of HER-2/neu immunohistochemical assay sensitivity and scoring on formalin-fixed and paraffin-processed cell lines and breast tumors: a comparative study involving results from laboratories in 21 countries. Am J Clin Pathol 2002;118:408-17.

5. Lewis F, Jackson P, Lane S, Coast G, Hanby AM. Testing for HER2 in breast cancer. Histopathology 2004;45:207-17.

6. Dietel M, Ellis IO, Höfler H, Kreipe H, Moch H, Dankof A, et al. Comparison of automated silver enhanced in situ hybridization (SISH) and fluorescence ISH (FISH) for the validation of HER2 gene status in breast carcinoma according to the guidelines of the American Society of Clinical Oncology and the College of American Pathologists. Virchows Arch 2007;451:19-25.

7. Shousha S, Peston D, Amo-Takyi B, Morgan M, Jasani B. Evaluation of automated silver-enhanced in situ hybridization (SISH) for detection of HER2 gene amplification in breast carcinoma excision and core biopsy specimens. Histopathology 2009;54:248-53.

8. Wolff AC, Hammond ME, Schwartz JN, Hagerty KL, Allred DC, Cote RJ, et al. American Society of Clinical Oncology/College of American Pathologists guideline recommendations for human epidermal growth factor receptor 2 testing in breast cancer. J Clin Oncol 2007;25:118-45.

9. Landis JR, Koch GG. The measurement of observer agreement for categorical data. Biometrics 1977;33:159-74.

10. Lakhani SR, Ellis IO, Schnitt SJ, Tan PH, Van de Vijver MJ. WHO Classification of Tumours of the Breast. 4th ed. Lyon: International Agency for Research on Cancer; 2012. p.8-38.

11. Park K, Kim J, Lim S, Han S. Topoisomerase II-alpha (topoII) and HER2 amplification in breast cancers and response to preoperative doxorubicin chemotherapy. Eur J Cancer 2003;39:631-4.

12. Dowsett M. Overexpression of HER-2 as a resistance mechanism to hormonal therapy for breast cancer. Endocr Relat Cancer 2001;8: 191-5.

13. Shak S. Overview of the trastuzumab (Herceptin) anti-HER2 
monoclonal antibody clinical program in HER2-overexpressing metastatic breast cancer. Herceptin Multinational Investigator Study Group. Semin Oncol 1999;26(4 Suppl 12):71-7.

14. Press MF, Hung G, Godolphin W, Slamon DJ. Sensitivity of HER-2/ neu antibodies in archival tissue samples: potential source of error in immunohistochemical studies of oncogene expression. Cancer Res 1994;54:2771-7.

15. Papadopoulos S, Kouvatseas G, Skarlos D, Malamos N, Delliou E, Saratsiotou I, et al. Comparison of HER2 detection methods between central and regional laboratories in Greece. Clin Breast Cancer 2007;7:784-90.

16. Paik S, Bryant J, Tan-Chiu E, Romond E, Hiller W, Park K, et al. Real-world performance of HER2 testing: National Surgical Adjuvant Breast and Bowel Project experience. J Natl Cancer Inst 2002;94: $852-4$.

17. Park K, Han S. A single institute's experience of standardization for the HER2 status by fluorescence in situ hybridization and immunohistochemistry on a primary breast cancer tissue microarray. J Korean Breast Cancer Soc 2004; 7:27-31.

18. Mass RD, Press MF, Anderson S, Cobleigh MA, Vogel CL, Dybdal $\mathrm{N}$, et al. Evaluation of clinical outcomes according to HER2 detection by fluorescence in situ hybridization in women with metastatic breast cancer treated with trastuzumab. Clin Breast Cancer 2005; 6:240-6.

19. Cobleigh MA, Vogel CL, Tripathy D, Robert NJ, Scholl S, Fehrenbacher L, et al. Multinational study of the efficacy and safety of humanized anti-HER2 monoclonal antibody in women who have HER2-overexpressing metastatic breast cancer that has progressed after chemotherapy for metastatic disease. J Clin Oncol 1999;17: 2639-48.

20. Tvrdík D, Staněk L, Skálová H, Dundr P, Velenská Z, Povýšil C. Comparison of the IHC, FISH, SISH and qPCR methods for the molecular diagnosis of breast cancer. Mol Med Rep 2012;6:439-43.

21. Jacquemier J, Spyratos F, Esterni B, Mozziconacci MJ, Antoine M, Arnould L, et al. SISH/CISH or qPCR as alternative techniques to FISH for determination of HER2 amplification status on breast tumors core needle biopsies: a multicenter experience based on 840 cases. BMC Cancer 2013;13:351.

22. Bae YK, Gong G, Kang J, Lee A, Cho EY, Lee JS, et al. HER2 status by standardized immunohistochemistry and silver-enhanced in situ hybridization in Korean breast cancer. J Breast Cancer 2012;15: $381-7$.

23. Meijer SL, Wesseling J, Smit VT, Nederlof PM, Hooijer GK, Ruijter $\mathrm{H}$, et al. HER2 gene amplification in patients with breast cancer with equivocal IHC results. J Clin Pathol 2011;64:1069-72.

24. Dowsett M, Procter M, McCaskill-Stevens W, de Azambuja E, Dafni U, Rueschoff J, et al. Disease-free survival according to degree of HER2 amplification for patients treated with adjuvant chemotherapy with or without 1 year of trastuzumab: the HERA Trial. J Clin Oncol 2009;27:2962-9.

25. Schalper KA, Kumar S, Hui P, Rimm DL, Gershkovich P. A retrospective population-based comparison of HER2 immunohistochemistry and fluorescence in situ hybridization in breast carcinomas: impact of 2007 American Society of Clinical Oncology/College of American Pathologists criteria. Arch Pathol Lab Med 2014; 138:213-9. 